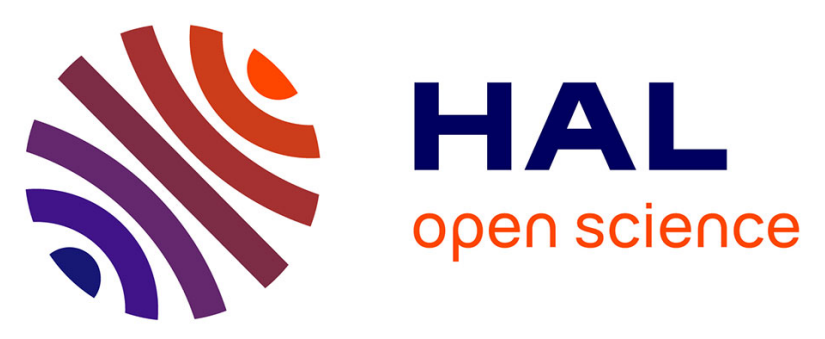

\title{
Morphofunctional traits reflect differences in phytoplankton community between rivers of contrasting flow regime
}

Stéphane Fraisse, Myriam Bormans, Yvan Lagadeuc

\section{- To cite this version:}

Stéphane Fraisse, Myriam Bormans, Yvan Lagadeuc. Morphofunctional traits reflect differences in phytoplankton community between rivers of contrasting flow regime. Aquatic Ecology, 2013,47 (3), pp.315-327. 10.1007/s10452-013-9446-z . hal-00861690

HAL Id: hal-00861690

https://hal-univ-rennes1.archives-ouvertes.fr/hal-00861690

Submitted on 13 Sep 2013

HAL is a multi-disciplinary open access archive for the deposit and dissemination of scientific research documents, whether they are published or not. The documents may come from teaching and research institutions in France or abroad, or from public or private research centers.
L'archive ouverte pluridisciplinaire $\mathbf{H A L}$, est destinée au dépôt et à la diffusion de documents scientifiques de niveau recherche, publiés ou non, émanant des établissements d'enseignement et de recherche français ou étrangers, des laboratoires publics ou privés. 


\title{
Morphofunctional traits reflect differences in phytoplankton community between rivers of contrasting flow regime
}

\author{
Stéphane Fraisse • Myriam Bormans • \\ Yvan Lagadeuc
}

Received: 29 November 2012/ Accepted: 3 July 2013/Published online: 12 July 2013

(C) Springer Science+Business Media Dordrecht 2013

\begin{abstract}
A morphofunctional traits approach has been adopted to identify how environmental factors shape the phytoplankton community. This approach has been applied in two rivers where hydrodynamical conditions are expected to be the main factor acting on the phytoplankton community. Hence, morphological traits (motility, shape, size, mucilage, and silica) related to sedimentation resistance have been chosen. We have shown that differences in flow regulation through differences in flow velocities induce shifts in phytoplankton community. These shifts depend mostly on shape, buoyancy regulation, and motility of phytoplankton cells. Elongated shapes are the characteristic of unregulated sites with high flow velocities, while cells able to regulate actively their position or to reduce their density (mucilaginous colonies) are found in regulated sites with low flow velocities. Flattened shapes are also the characteristic of sites with rather low flow velocities. These results highlight the key role of flow velocity as a driving factor controlling the structure of phytoplankton community. In this study, flow velocity also structures phytoplankton community according to location rather than seasonality.
\end{abstract}

Handling Editor: Bas W. Ibelings.

S. Fraisse $(\varangle) \cdot$ M. Bormans $\cdot$ Y. Lagadeuc

Université de Rennes 1, UMR CNRS 6553 ECOBIO,

Campus de Beaulieu, 35042 Rennes Cedex, France

e-mail: steph.fraisse@gmail.com
Keywords Morphofunctional traits - Shape Flow velocity · Buoyancy ·

Phytoplankton community structure

\section{Introduction}

To explain and predict phytoplankton community composition, functional approaches are increasingly adopted. They are based on the assumptions that (1) phytoplankton is composed of several groups of species responding similarly to environmental conditions; (2) their occurrence depends on the dynamics and relative importance of environmental factors (Weithoff 2003). Groups originally developed by Reynolds (1980) and subsequently refined (Reynolds et al. 2002; Padisák et al. 2009) constitute one of the most used functional approaches and have been extensively adopted to explain phytoplankton community structure (e.g., Gurbuz et al. 2003; Becker et al. 2008; Bovo-Scomparin et al. 2013). Functional groups are constituted of species typically found at given environmental conditions and sharing similar functional traits (Reynolds et al. 2002) that are any morphological, physiological, or phenological features affecting ecological performance (McGill et al. 2006; Violle et al. 2007). Complementary functional approaches are springing up, aiming to build a priori functional groups only based on functional traits (Weithoff 2003; Kruk et al. 2010). Hence, a key step to adopt such an approach is the identification of the 
relevant functional traits depending on environmental conditions acting on the community. However, physiological functional traits are not always easily measurable, inducing some difficulties to build a priori functional classifications for community composition prediction (Kruk et al. 2010). By contrast, morphological traits are more accessible because of their ease to be measured (Weithoff 2003). Although they do not all reflect the ecological phytoplankton cells properties, they constitute a great proxy for physiological traits. Indeed, several authors have shown a positive correlation between size and nutrient uptake (Reynolds 2006; Litchman and Klausmeier 2008), shape and resistance to sedimentation (Padisák et al. 2003), or between size and light acquisition (Finkel et al. 2004; Schwaderer et al. 2011). Recently, Zhang et al. (2011) even showed that the photosynthetic efficiency within the same species varied with its morphology. Hence, some functional approaches based on morphological (or morphofunctional) traits have been built and successfully applied (Salmaso and Padisák 2007; Mieleitner et al. 2008; Longhi and Beisner 2010; Kruk et al. 2010). Recently, Kruk et al. (2011) tested their morphology-based functional groups (MBFC) against environmental conditions for a large dataset (211 lakes) covering a wide range of conditions. They showed that more variation in phytoplankton community that was mainly attributed to nutrients (silica and nitrogen) and differences in grazer abundance can be explained using MBFG than using Reynolds functional groups (Reynolds et al. 2002).

In rivers, some functional studies have recently been conducted explaining for instance the natural changes of phytoplankton in the Loire River (Abonyi et al., 2012) or the phytoplankton community response to extreme hydrological event in the Paraná River (Devercelli 2010). They were performed using Reynolds functional groups (Reynolds et al. 2002) but other studies have also been conducted using morphofunctional approaches (Centis et al. 2010; Stankovic et al. 2012). However, both reported studies based on morphological approaches had some limitations. On one hand, the morphofunctional classification of Centis et al. (2010) only considered diatoms, while other groups can constitute a significant part of the community. On the other hand, the morphologicalbased functional classification used by Stankovic et al. (2012) in four rivers in Croatia was originally designed for lakes; the authors showed that it was not applicable for rivers since the relative importance of driving forces controlling the phytoplankton community is different in rivers than in lakes. Hence, an approach with morphofunctional traits that are related to the dominant factors in rivers is still lacking.

Physical factors, in particular flow, often show a continuous gradient from upstream to downstream resulting in a continuum of biotic adjustments described as the river continuum concept (Vannote et al. 1980). Thus, physical factors are known to play a key role on river phytoplankton community. Moreover, in rivers impacted by flow regulation, the range of values of these physical factors is enhanced (Stevenson and White 1995; Reynolds and Descy 1996; Bormans and Condie 1998; Salmaso and Zignin 2010). Numerous morphological traits responding to flow and affecting the sinking velocity then could be key traits that could explain phytoplankton differences under contrasting hydrodynamical conditions. Motility and in particular the presence of flagella confers an advantage in less turbulent conditions since cells are able to regulate their position in the water column (Jones 1988; Tam and Hosoi 2011). Buoyancy regulation by reducing cell density through the presence of gas vesicles or a large amount of mucilage (Reynolds 2007) is also an advantage in such environmental conditions. The presence of silica, which increases density and sinking rate, is a disadvantage in stagnant water (Sommer 1996). Shape plays a key role, as Padisák et al. (2003) demonstrated its impact on the sinking velocity and in particular that the symmetrical localization of cells in a flattened colony could reduce the sedimentation rate by increasing the form resistance $(\varphi)$. Three types of shape can be distinguished: flattened, spherical, and elongated shape. Size is also a key trait involved in settling velocity since larger cell sink faster than smaller ones (Pannard et al. 2007). In this context of sedimentation, it is the size of the entire colony or filament that is relevant.

The aim of this study is to show whether an approach based on morphofunctional traits could be used in rivers to predict phytoplankton community composition. As this approach is scarcely used in rivers, we chose simple systems diverging in terms of flow regulation and where hydrodynamical conditions are expected to be the main factor acting on the community. Hence, we hypothesized that morphofunctional traits mentioned above (motility, shape, 
density, and size) related to sedimentation resistance could be used to differentiate phytoplankton community structures in these rivers. We first chose a wide selection of traits and attempted to identify the most relevant ones.

\section{Materials and methods}

Morphofunctional traits selection

We chose morphofunctional traits related to sedimentation resistance mentioned in the introduction: motility, shape, density, and size. Combination of these traits resulted in 14 groups used to test our hypothesis (Table 1). Considering these traits, more than 14 groups could have been constituted, but corresponding species did no not occur at the sampling sites. Through these groups, we do not aim to propose a generalizable classification, but just to test whether morphological traits can be used to explain phytoplankton community in rivers.

We made the choice to gather unidentified two Nostocales and Oscillatoriales species in Group N. Indeed, depending on their taxonomical affiliation, they can be pelagic (and display gas vesicles) or benthic. We considered the two possible origins to explain our results.

\section{Study area}

We investigated the phytoplankton community in two rivers, Aulne and Elorn. They are located in Brittany (France) and constitute the main river input in the coastal ecosystem of the Rade de Brest (Fig. 1). They are in the same geological and geographical context and with the same agricultural pressure inducing similar nutrient inputs. The Aulne River is more developed than the Elorn River with flow regulation at its downstream end. Six sites displaying some differences in terms of flow regulation were chosen. In this paper, the term regulation is applied for sites where flow is controlled by weirs. Conversely, unregulated sites are free of weirs. We chose 4 sites on the Aulne River: Au1 $\left(48^{\circ} 20^{\prime} \mathrm{N}, 3^{\circ} 41^{\prime} \mathrm{W}\right), \mathrm{Au} 2\left(48^{\circ} 15^{\prime} \mathrm{N}, 3^{\circ} 42^{\prime}\right.$ $\mathrm{W}), \mathrm{Au} 3\left(48^{\circ} 11^{\prime} \mathrm{N}, 3^{\circ} 48^{\prime} \mathrm{W}\right)$, and $\mathrm{Au} 4\left(48^{\circ} 11^{\prime} \mathrm{N}, 4^{\circ} 4^{\prime}\right.$ $\mathrm{W})$ and two sites on the Elorn River: El1 $\left(48^{\circ} 24^{\prime} \mathrm{N}\right.$, $\left.4^{\circ} 4^{\prime} \mathrm{W}\right)$ and El2 $\left(48^{\circ} 28^{\prime} \mathrm{N}, 4^{\circ} 13^{\prime} \mathrm{W}\right)$. Au1 and Au2, the upstream sites of the Aulne River, are free of weirs as are El1 and El2. These sites are rather shallow $(0.4-0.75 \mathrm{~m})$. By contrast, Au3 and Au4 are more developed with several weirs to increase depth (1.7 and $2 \mathrm{~m}$, respectively).

Sampling and physicochemical analyses

Three field sampling periods were carried out in May 2009, July, and September 2010. Sites were sampled four (May and July) and five (September) times within three weeks. Temperature, $\mathrm{pH}$, conductivity, dissolved oxygen, turbidity, photosynthetically active radiation (PAR), and chlorophyll fluorescence vertical profiles were undertaken at each site using a Idronaut $316+$ probe (Idronaut, Milan). Using PAR profiles provided by the probe, we identified the euphotic zone depth (Zeu) and then the Zeu/Zm (Zm: maximal depth) ratio was calculated. Samples of water were taken at $0.5 \mathrm{~m}$ below the surface water with a horizontal 2-L Van Dorn bottle. Filtered (Whatman GF/F) water was analyzed by colorimetric methods for $\mathrm{NO}_{3}{ }^{-}$(Barnes and Folkard 1951) and total dissolved phosphorus (TDP) (Murphy and Riley 1962) concentration. Due to dosage problem, TDP values for the July field samples were not available. Unfiltered samples were also taken and analyzed for total nitrogen (TN) and total phosphorus (TP) by persulfate digestion. All nutrients determinations were performed by automated flow injection analyses (BRAN + LUEBBE, Autoanalyzer III). Two other filtrations were done to determine total suspended solid (TSS) and phytoplankton biomass as chlorophyll- $a$ (described below). TSS filters were dried at $105^{\circ} \mathrm{C}$ and weighted. Ashing to $550{ }^{\circ} \mathrm{C}$ was also done to determine the organic part.

Flow velocities were measured in situ using a mechanical current meter, and we calculated at each site the Froude number $(\mathrm{Fr})$ that is a dimensionless number $\left(F r=V /(g h)^{1 / 2}\right)$ where $V$ is the water velocity $\left(\mathrm{m} \mathrm{s}^{-1}\right), \quad g$ the acceleration due to gravity (9.81 $\left.\mathrm{m} \mathrm{s}^{-1}\right)$, and $h$ the water depth (m) and reflect the hydrodynamical conditions. It has been used in rivers to distinguish pool, run, and riffles habitats (Jowett 1993). The residence time between each site was also estimated using flow velocities values, distance between sites and river section. Vegetation cover was estimated by a GIS approach (ArcGis 9.2) to evaluate the shading effect. An index was calculated 
Table 1 Selected traits combinations

\begin{tabular}{|c|c|c|c|c|c|}
\hline \multirow[t]{11}{*}{$\begin{array}{l}\text { Absence of motility } \\
\text { structure }\end{array}$} & Colonial form & $\begin{array}{l}\text { Flattened } \\
\text { shape }\end{array}$ & Presence of silica & MLD $>25 \mu \mathrm{m}$ & $\begin{array}{l}\text { Group A (Asterionella } \\
\text { formosa; Nitzschia } \\
\text { fruticosa) }\end{array}$ \\
\hline & & & Absence of silica & MLD $>25 \mu \mathrm{m}$ & $\begin{array}{l}\text { Group B (Pediastrum } \\
\text { boryanum; Pediastrum } \\
\text { duplex) }\end{array}$ \\
\hline & & & & MLD $<25 \mu \mathrm{m}$ & $\begin{array}{l}\text { Group D (Actinastrum } \\
\text { hantzschii; Pediastrum } \\
\text { tetras) }\end{array}$ \\
\hline & & $\begin{array}{l}\text { Spherical } \\
\text { shape (3D) }\end{array}$ & $\begin{array}{l}\text { Presence of large } \\
\text { amount of } \\
\text { mucilage }\end{array}$ & MLD $>25 \mu \mathrm{m}$ & $\begin{array}{l}\text { Group E (Eudorina } \\
\text { elegans; Sphaerocystis } \\
\text { sp.) }\end{array}$ \\
\hline & $\begin{array}{l}\text { Filamentous } \\
\text { species } \\
\text { (elongated } \\
\text { shape) }\end{array}$ & MLD $>25 \mu \mathrm{m}$ & & & $\begin{array}{l}\text { Group F (Melosira } \\
\text { varians; Spondylosium } \\
\text { pulchellum) }\end{array}$ \\
\hline & Solitary form & $\begin{array}{l}\text { Flattened } \\
\text { shape }\end{array}$ & Presence of silica & MLD $<25 \mu \mathrm{m}$ & $\begin{array}{l}\text { Group G (Cyclotella sp.; } \\
\text { Stephanodiscus sp.) }\end{array}$ \\
\hline & & $\begin{array}{l}\text { Spherical } \\
\text { shape }\end{array}$ & Absence of silica & MLD $<25 \mu \mathrm{m}$ & $\begin{array}{l}\text { Group H (Tetraedron sp.; } \\
\text { Cosmarium } \mathrm{sp} .)\end{array}$ \\
\hline & & $\begin{array}{l}\text { Elongated } \\
\text { shape }\end{array}$ & Presence of silica & MLD $<25 \mu \mathrm{m}$ & Group I (Craticula sp.) \\
\hline & & & & MLD $>25 \mu \mathrm{m}$ & $\begin{array}{l}\text { Group J (Nitzschia } \\
\text { acicularis; Navicula } \\
\text { lanceolata) }\end{array}$ \\
\hline & & & Absence of silica & $\operatorname{MLD}<25 \mu \mathrm{m}$ & $\begin{array}{l}\text { Group K (Hyaloraphidium } \\
\text { sp.; Selenastrum sp.) }\end{array}$ \\
\hline & & & & MLD $>25 \mu \mathrm{m}$ & $\begin{array}{l}\text { Group L (Closterium } \\
\text { acutum; Closterium } \\
\text { monoliferum) }\end{array}$ \\
\hline \multirow[t]{3}{*}{$\begin{array}{l}\text { Presence of motility or } \\
\text { buoyancy regulation } \\
\text { structure }\end{array}$} & MLD > $25 \mu \mathrm{m}$ & With flagella & & & $\begin{array}{l}\text { Group M (Trachelomonas } \\
\text { oblonga; Cryptomonas } \\
\text { sp.) }\end{array}$ \\
\hline & & With aerotopes & & & $\begin{array}{l}\text { Group N (Woronichinia } \\
\text { naegeliana) }\end{array}$ \\
\hline & $\operatorname{MLD}<25 \mu \mathrm{m}$ & With flagella & & & $\begin{array}{l}\text { Group O (Nephroselmis } \\
\text { olivacea; Rhodomonas } \\
\text { sp.) }\end{array}$ \\
\hline
\end{tabular}

For each combination, two examples of dominant species are given (maximum linear dimension (MLD) ( $\mu \mathrm{m})$ of the unicellular, the colony or the filament)

integrating an upstream zone corresponding to a residence time of three days at each site. For the most upstream site, Au1 and El1, the river upstream limit constrained the residence time to one day. For the index determination, a buffer zone of $10 \mathrm{~m}$ on both sides of the river was drawn to calculate the ratio of the buffer surface intersecting vegetation to the total surface (river and buffer zone) to obtain a percentage of vegetation cover. While it is a simple index, it was sufficiently accurate to reveal differences between sites.
Phytoplankton biomass and community structure

For chlorophyll- $a$ extraction, filters were placed in $90 \%$ acetone at $4{ }^{\circ} \mathrm{C}$ in dark vials during $24 \mathrm{~h}$. Then, concentration was determined spectrophotometrically before and after acidification with hydrochloric acid (Lorenzen 1967). From chlorophyll- $a$ concentrations, we estimated phytoplankton cell carbon values following a 60:1 ratio. Phytoplankton samples were fixed with Lugol's acidified solution (1\%) and kept in the dark before counting. Fresh samples were also 


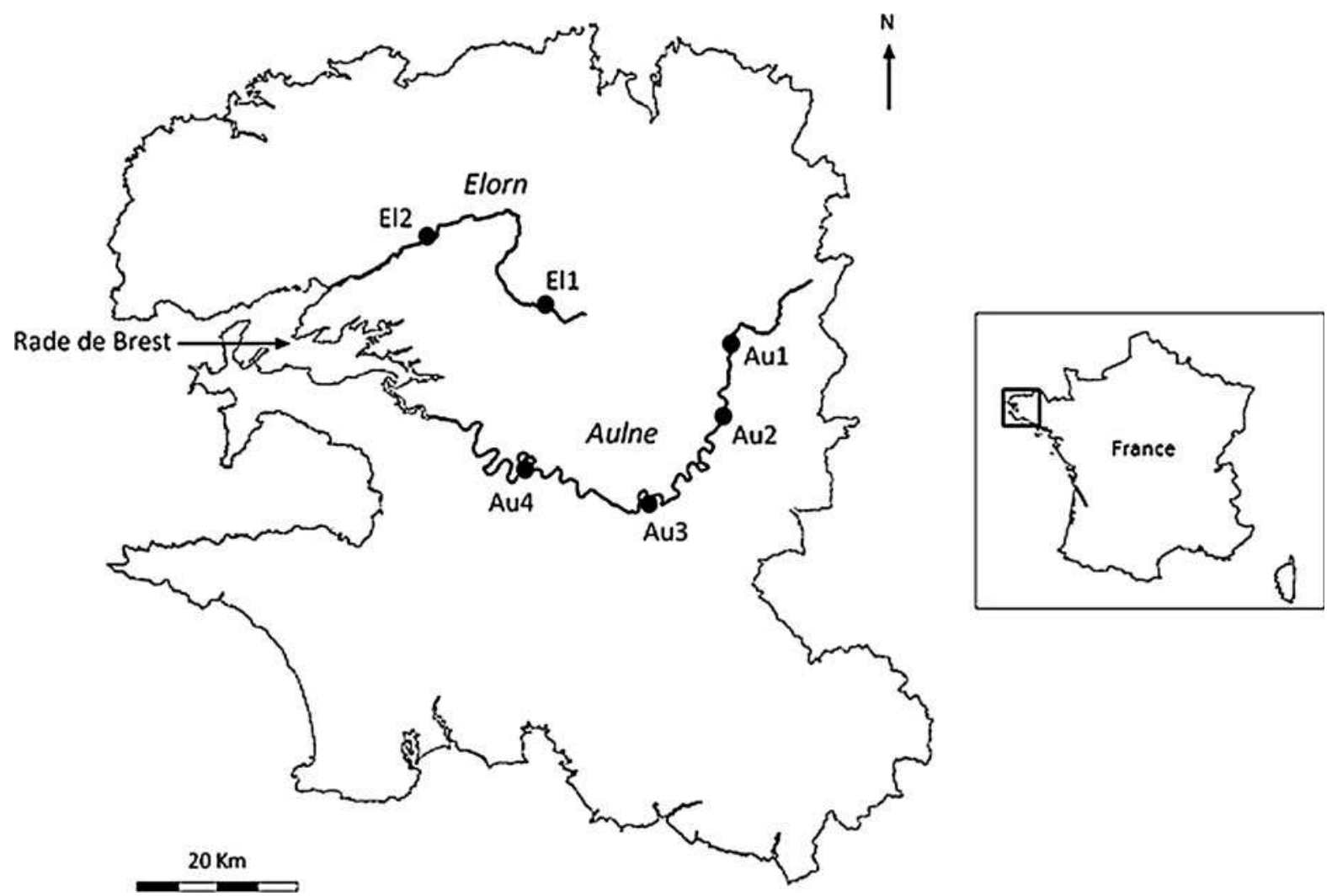

Fig. 1 Location of sampling stations. Au corresponds to sites along the Aulne River and El to sites along the Elorn River. The smallest numbers correspond to upstream sites and the highest numbers correspond to downstream sites

collected to perform taxonomical identification. Algal counts and taxonomical identification were conducted with inverted microscope (Lund et al. 1958), and biovolumes were calculated from the measurement of at least 10 individual cells of each species in each sample following Hillebrand et al. (1999) and Sun and Liu (2003). According to the combination of their morphofunctional traits, phytoplankton taxa were distributed into the different functional groups (Table 1).

\section{Statistical analyses}

To show differences in phytoplankton structure between sites, we calculated the Hellinger distance between each pair of sites according to the biovolume of morphofunctional groups. Hellinger distance was chosen because it is not influenced by the double zero and by total biomass differences (Legendre and Legendre 1998; Lagadeuc et al. 1997). We obtained a distance matrix on which we applied the Ward clusterization method to obtain a dendrogram quantifying differences between sites according to their phytoplankton structure. A correspondence analysis (CA) was also done to show how functional groups characterized the clusters of sites. All statistical analyses were performed with the $\mathrm{R}$ software ( $\mathrm{R}$ Development Core Team 2010). Hellinger distance and multivariate analysis were performed with Vegan (Oksanen et al. 2010) and Ade4 (Dray and Dufour 2007) package, respectively.

\section{Results}

Environmental conditions

As expected, regulated and unregulated sites clearly showed different physical conditions. Calculated daily flow velocities from the water discharge values are shown in Fig. 2a. Two groups of sites can be drawn: those with low flow velocity (Au2, Au3, and Au4, 
mean $\left.\pm \mathrm{SD}=0.08 \pm 0.09 \mathrm{~m} \mathrm{~s}^{-1}, n=39\right)$ and the others with high flow velocity (Au1, El1, and El2, mean $=0.52 \pm 0.42 \mathrm{~m} \mathrm{~s}^{-1}, n=39$ ). These flow velocities corresponded to a Froude number varying between 0 and 0.07 for sites Au2, Au3, and Au4 and between 0.05 and 1.07 with most values above 0.1 in sites Au1, El1, and El2. Higher values in these sites reflect that they were more turbulent than Au2, Au3, and Au4. Seasonal variations in flow velocities occurred, with higher values in May for sites Au2, $\mathrm{Au} 3$, and Au4 $\left(0.13 \pm 0.04 \mathrm{~m} \mathrm{~s}^{-1}(n=12)\right.$ versus $0.02 \pm 0.01 \mathrm{~m} \mathrm{~s}^{-1} \quad(n=12) \quad$ in July and $0.09 \pm 0.12 \mathrm{~m} \mathrm{~s}^{-1}(n=15)$ in September $)$ and the lowest values in July for both groups. The water residence time is longer at regulated sites (range 1.5-11.4 days, Table 2) than at unregulated sites. At the latter, water residence time was particularly short, especially in May when it never excessed 0.5 days. The last days of the September sampling period were two heavy rainy days inducing higher values in flow velocities. Total suspended solids (TSS) concentrations were low and exhibiting values never exceeding $15 \mathrm{mg} \mathrm{L}^{-1}$ (Fig. 2b) These low TSS concentrations resulted in high Zeu/Zm ratio ( $>1$ ) (Fig. 2c) indicating that underwater light availability was high enough to sustain photosynthesis through the entire water column. However, unregulated sites displayed higher $\mathrm{Zeu} / \mathrm{Zm}$ ratio $(3.17 \pm 0.8)$ than regulated sites $(2.06 \pm 0.7)$. They also exhibited differences in vegetation cover (Fig. 2c). In narrow rivers, the vegetative cover can affect the light climate in the water column through shading. In this study, sites Au1, El1, and El2 had a high vegetation cover (>60\%), while sites Au2, Au3, and Au4 had a vegetation cover that never exceeded $30 \%$.

Through all sampling periods, the unregulated site E12 on the Elorn River showed the highest concentration of nitrate (Fig. 2d). Along the Aulne River, nitrate concentration was homogeneous across sites $(155.4 \pm 41.5 \mu \mathrm{M} \quad(n=16) ; \quad 110.7 \pm 36.2 \mu \mathrm{M}$ $(n=20)$ in July and September, respectively), except in May when regulated sites Au3 and Au4 exhibited higher values $(357.2 \pm 37.5 \mu \mathrm{M} \quad(n=8)$ versus $162.9 \pm 64.7 \mu \mathrm{M}(n=8)$ in $\mathrm{Au} 1$ and Au2). TDP concentrations (Fig. 2e) ranged from 0.20 to $1.37 \mu \mathrm{M}$ in unregulated sites and from 0.28 to $1.10 \mu \mathrm{M}$ in regulated sites in May. TDP concentration ranges were similar in September varying from 0.16 to $1.53 \mu \mathrm{M}$ in unregulated sites and from 0.16 to $1.38 \mu \mathrm{M}$ in regulated sites. In light of the generally low chlorophyll- $a$ concentration (mean $=3.63 \pm 4.29 \mu \mathrm{g} \mathrm{L}^{-1}$, $n=78$ ), it appears that nutrients were not limiting for phytoplankton growth either in the regulated or unregulated sites. Indeed, even when TDP was very low $(0.17 \mu \mathrm{M}$ in Au1 and $0.16 \mu \mathrm{M}$ in Au2), phytoplankton carbon-to-total dissolved phosphorus ratio and phytoplankton carbon-to-total dissolved nitrogen ratio never exceeded 106 and 6.25, respectively.

\section{Phytoplankton biomass and community structure}

Average phytoplankton biomass, measured as chlorophyll- $a$ concentration, was higher in regulated sites $\left(6.4 \pm 5.8 \mu \mathrm{g} \mathrm{L}^{-1} ; n=26\right)$ than in unregulated sites $\left(2.1 \pm 2.2 \mu \mathrm{g} \mathrm{L}^{-1} ; n=52\right)$ during the three sampling periods.

Taxonomic analysis showed that benthic species did not exceed $20 \%$ of the whole community biomass for 44 of the total 54 samples (20-30\% for 6 of them and $30-50 \%$ for the last ones).

Sites' clustering using the Ward method showed that they could be split into 6 groups according to the biovolume of their functional groups (Fig. 3). Among these, there are three groups of unregulated sites and three groups of regulated sites. The largest differences obtained in the phytoplankton structure are based on location (regulated versus unregulated sites). For regulated sites, seasonal variation occurs at a lower clustering level discriminating sites sampled in May and sites sampled in July and in September. The correspondence analysis (CA) also suggests that phytoplankton variability between sites can be explained in terms of morphofunctional traits (Fig. 4 (sites were hidden to increase the readability) and Fig. 5). The two first axes explained $50 \%$ of the total variation. Axis 1 discriminates functional Group $G$ from Groups E, O, and M (Fig. 4). Flagellated cells (Group O and Group M) were associated with Group $\mathrm{E}$, which gathers species organized in spherical colonies and displaying a large amount of mucilage. At the opposite of Axis 1, the Group G is constituted by spherical cells with silica. Hence, in terms of functional traits, Axis 1 separates cells with silica from flagellated cells and mucilaginous colonies and therefore seems to be associated with the presence of structure reducing sinking velocities (flagellate and large amount of mucilage). Axis 2 allows the discrimination of three groups: (1) flagellated cells 
Fig. 2 Spatial and temporal variations of measured values of a flow velocities, b TSS, c vegetation cover (white histogram, left axis) and $\mathrm{Zeu} / \mathrm{Zm}$ ratio (black square, right axis), $\mathbf{d}$ nitrate, e TDP (July concentrations not available), and f chlorophyll-

$a$ concentration in the Aulne and the Elorn Rivers. Gray, black, and empty circles correspond to data sampled in May, July, and September, respectively
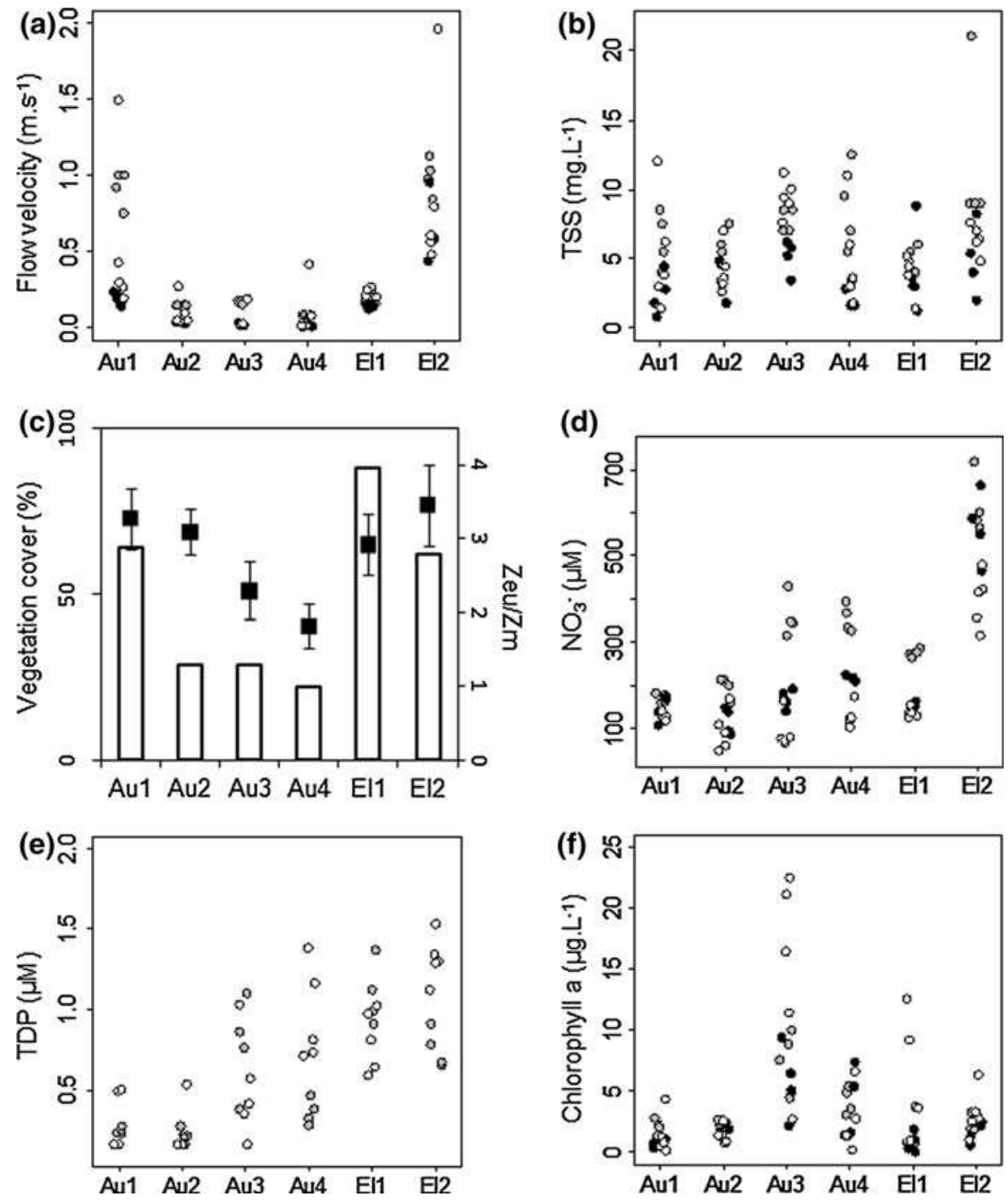

Table 2 The water residence time (days) between sites in May, July, and September

\begin{tabular}{lllcl}
\hline Residence time & $\mathrm{Au} 1-\mathrm{Au} 2$ & $\mathrm{Au} 2-\mathrm{Au} 3$ & $\mathrm{Au} 3-\mathrm{Au} 4$ & $\mathrm{El1-El2}$ \\
\hline May & 0.36 & 1.61 & 1.96 & 0.28 \\
July & 1.63 & 7.69 & 9.78 & 0.63 \\
September & 1.20 & 6.58 & 11.41 & 0.88 \\
\hline
\end{tabular}

and colonies with mucilage, (2) flattened shape (Group D, Group B, and Group A), and (3) elongated shape (Group F, Group I, Group J, and Group L) suggesting shape variation gradient. Size does not appear as a key factor structuring the community because the four largest groups identified in the CA were mainly related to motility and shape. Group $\mathrm{N}$ is composed of cells that can actively regulate their buoyancy, and the fact that it is associated with filamentous and elongated shape is a surprising result that will be discussed later.

The sites' clusters from Fig. 3 were positioned on the CA (Fig. 4). Their location in the factorial space shows that overlapping between clusters of unregulated sites (ellipses 1, 2, and 5) and clusters of regulated sites (ellipses 3, 4, and 6) is limited, displaying differences in community structure in terms of morphofunctional traits related to flow regulation (Fig. 4). Figure 5 shows how functional groups explain the variability between unregulated and regulated sites. Regulated sites in May are associated with spherical cells with silica while they are dominated by flagellated cells and mucilaginous 


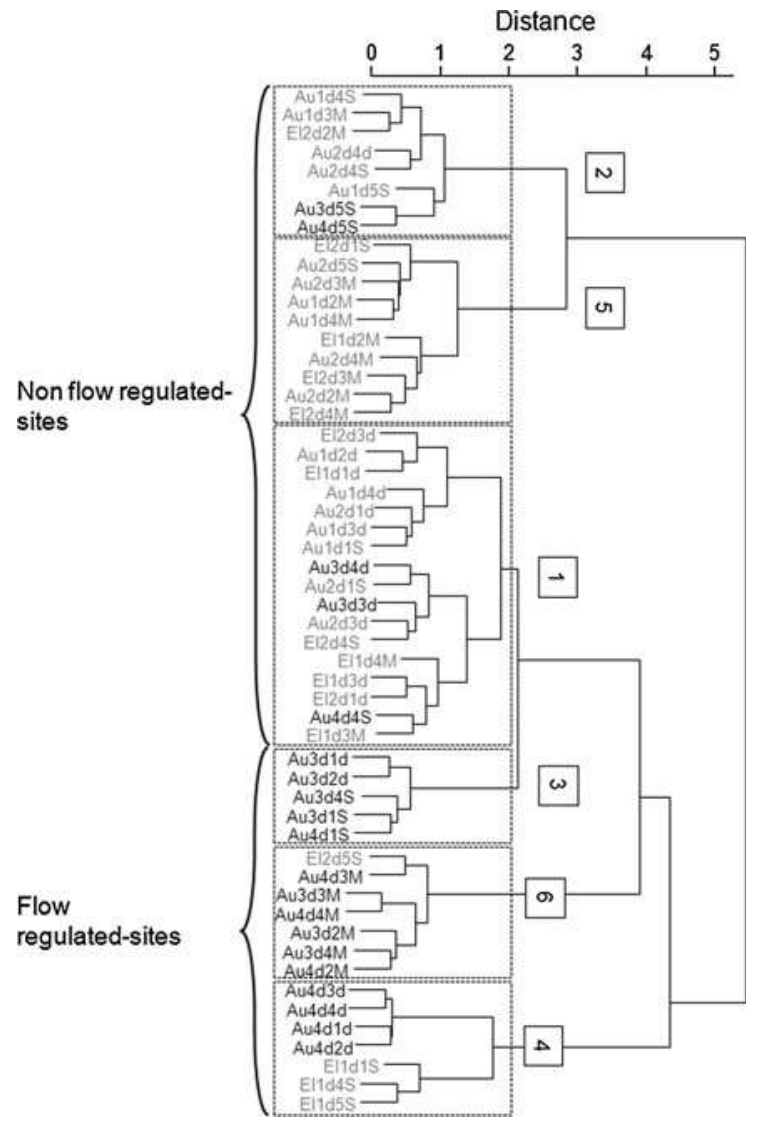

Fig. 3 Hierarchical clustering (Ward method) on the distance matrix (Hellinger distance) of Aulne and Elorn sites based on their morphofunctional group composition. Au1 corresponds to the Aulne most upstream site, Au4 to the Aulne most downstream site, El1 to the Elorn upstream site, and El2 to the Elorn downstream site; d1M, day 1 in May; d1J, day 1 in July; d1S, day 1 in September. Regulated sites are written in black script and unregulated sites in gray script

colonies in July and September. Clusters of unregulated sites are dispersed along Axis 2. Two clusters (5 and 2) are associated with filamentous, elongated shape, and cells with gas vesicles. However, the other one (cluster 1) gathering regulated and unregulated sites is associated with flattened colonies. Among these unregulated sites gathered by this cluster, we find a high proportion of data collected in site Au2 displaying low flow velocities (Fig. 2a) especially where vectors embodying flattened shape are present on the CA.

The goal of our approach was to select the most relevant morphofunctional traits that explain phytoplankton community structure. Thus, from this initial analysis, we retain four traits: flagella, mucilage, gas vesicles, and shape. A new CA was performed based on these four traits leading five combinations (Fig. 6). The main difference with the previous one is that more than $75 \%$ compared to $50 \%$ of the total variation is now explained by the first two axes. In addition, this new CA reduces overlapping between clusters 1,2 , and 3 (regulated sites) and clusters 4, 5, 6, and 7 (unregulated sites). This result highlights the relevance of these four traits to explain the differences of community structure we detected. By contrast, when the CA was conducted using taxonomic data (genus or class), all sites clusters overlapped. Neither genus nor class led to discriminate cluster sites as they are homogenously distributed in the CA projection.

\section{Discussion}

Phytoplankton biomass was found to increase from upstream to downstream, which is probably linked to the increase in water residence time (WRT) that is in accordance with many others studies (Reynolds 1994; Stevenson and White 1995; Tavernini et al. 2011). The phytoplankton community structure also varied across sampling sites that differed in terms of flow regulation resulting in differences in flow velocities and light availability. When we used taxonomy (class or genus level) to explain these observations, neither clear seasonal nor location distribution patterns could be identified. By contrast, these differences in community structure could be explained using morphofunctional traits as Kruk et al. (2011) showed.

Flow velocity, closely related to turbulence level, seemed to play a key role in structuring the phytoplankton community. In regulated systems, turbulence is low and species able to regulate their buoyancy have a competitive advantage over sinking species (Descy and Gosselain 1994; Dokulil 1994; Bormans and Condie 1998). In particular, our results showed that regulated sites were associated with flagellated cells that can actively regulate their position in the water column. Colonial species displaying large amount of mucilage, reducing their density and thus their sinking velocity (Reynolds 2006) were also associated with regulated sites. During May, these sites exhibited higher flow velocities values and were more turbulent than in July and September, resulting in the clear separation in phytoplankton structure. The phytoplankton community was dominated by small 
Fig. 4 Correspondence analysis (CA) showing the sites dispersion according to their functional groups composition. Au1 corresponds to the Aulne most upstream site, Au4 to the Aulne most downstream site, El1 to the Elorn upstream site and El2 to the Elorn downstream site; d1M, day 1 in May; d1J, day 1 in July; d1S, day 1 in September. Regulated sites are written in black script and unregulated sites in gray script

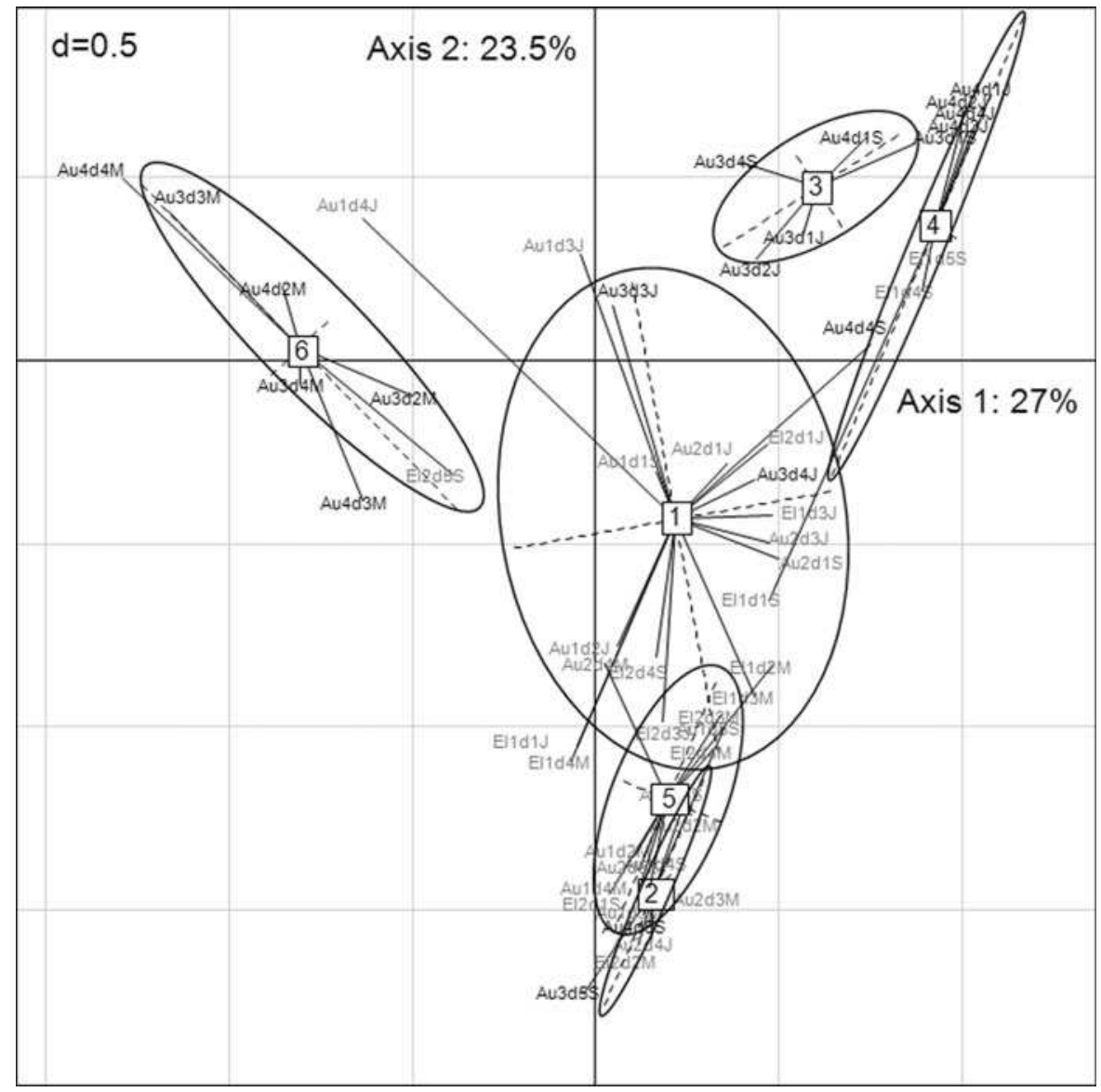

spherical siliceous cells maintained in the water column by the higher turbulence level. By contrast, in unregulated sites, phytoplankton community was characterized by species showing morphological features not adapted to sedimentation resistance. The similar trait that they shared is their elongated shape, highlighting the key role of shape. These results are in accordance with our expectations that elongated shapes are the characteristic of turbulent sites maybe because they sink faster. Hence, they require a turbulence intensity high enough to maintain them in the water column (Sherman et al. 1998; Condie and Bormans 1997; Huisman et al. 2002).

Group $\mathrm{N}$ is the characteristic of species able to regulate their buoyancy with gas vesicles. However, it is associated with groups showing a low resistance to sedimentation. As we previously stated, Group $\mathrm{N}$ also gathers cyanobacteria that were not identified at the species level. These cyanobacteria belong to Nostocales, a taxonomical group constituted of pelagic (displaying gas vesicles) and benthic species. Hence, if these species are pelagic, this unexpected result can be explained by a potential flushing of allochthonous cells. Indeed, the highest contribution to this group occurred after high precipitations causing possible overflowing of ponds located nearby. On the other end, if these species are benthic, they may have been torn from the substratum due to higher turbulence level caused by these high precipitations.

Between these two extremes types of traits (elongated shape and cells reducing their sinking velocity with flagella or large mucilage amount), another group is constituted by flattened shape. This shape confers a high resistance to sinking (Padisák et al. 2003) and should therefore be the characteristic of sites with rather low turbulence level. This is consistent with our results since it was associated with some regulated sites and several samples of an unregulated site displaying relatively low flow velocities (Au2). 
Fig. 5 The same CA that in Fig. 4 showing the explanatory variables (functional groups) of the sites dispersion. Axis 1 and Axis 2 explained $50.5 \%$ of the total inertia

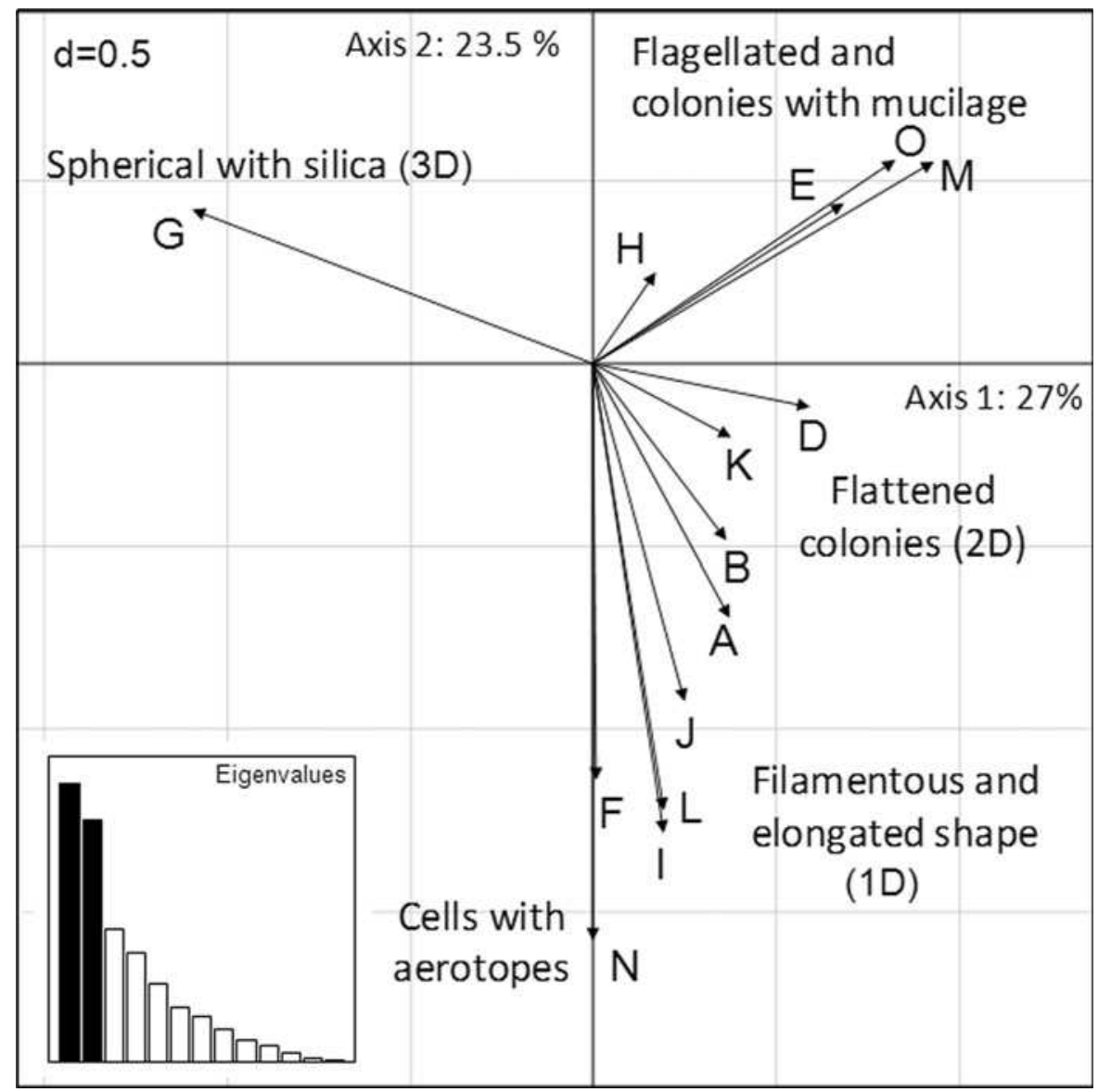

Besides affecting turbulence level, flow may also play a role on phytoplankton community through water residence time (WRT). As we previously stated, WRT acts on phytoplankton biomass, but the question arises whether it can affect the community structure. WRT should act on morphofunctional traits related to growth rate, selecting species able to grow faster at sites displaying shorter values (Chételat et al. 2006). However, we do not know any phytoplankton species able to double its population in less than two days (Edwards et al. 2012). Hence, at the low residence times observed at unregulated sites, we do not expect any morphological trait to respond. Nevertheless, residence time can indirectly affect the observed community structure since species sampled at a given site could be advected from upstream. In this case, traits selection also reflects upstream conditions. It is the case of Au2, for instance, which is characterized by low flow velocity and low vegetation cover but grouped with other unregulated site according to community structure. This highlights that such approach has to be adopted carefully in rivers as upstream reaches cannot be ignored since they can explain a part of the phytoplankton community structure.

Regulated and unregulated sites also display differences in light availability reflected by two indexes: Zeu/Zm (positively correlated with light availability) and vegetation cover (negatively correlated with light availability). However, depending on the index, different light availability patterns arise since regulated sites display lower vegetation cover but lower $\mathrm{Zeu} / \mathrm{Zm}$ than unregulated sites. Relative importance of these two features in the light intensity was not quantified in our study. Hence, even though cell size is a morphofunctional trait generally related to light acquisition (Finkel et al. 2004; Schwaderer et al. 2011), in our study, it may not have displayed a clear distribution pattern. A continuous measurement of light intensity at each site would have provided real 
Fig. 6 Correspondence analysis using the most relevant morphofunctional traits explaining the phytoplankton community structure. Axis 1 and Axis 2 explained $77 \%$ of the total inertia

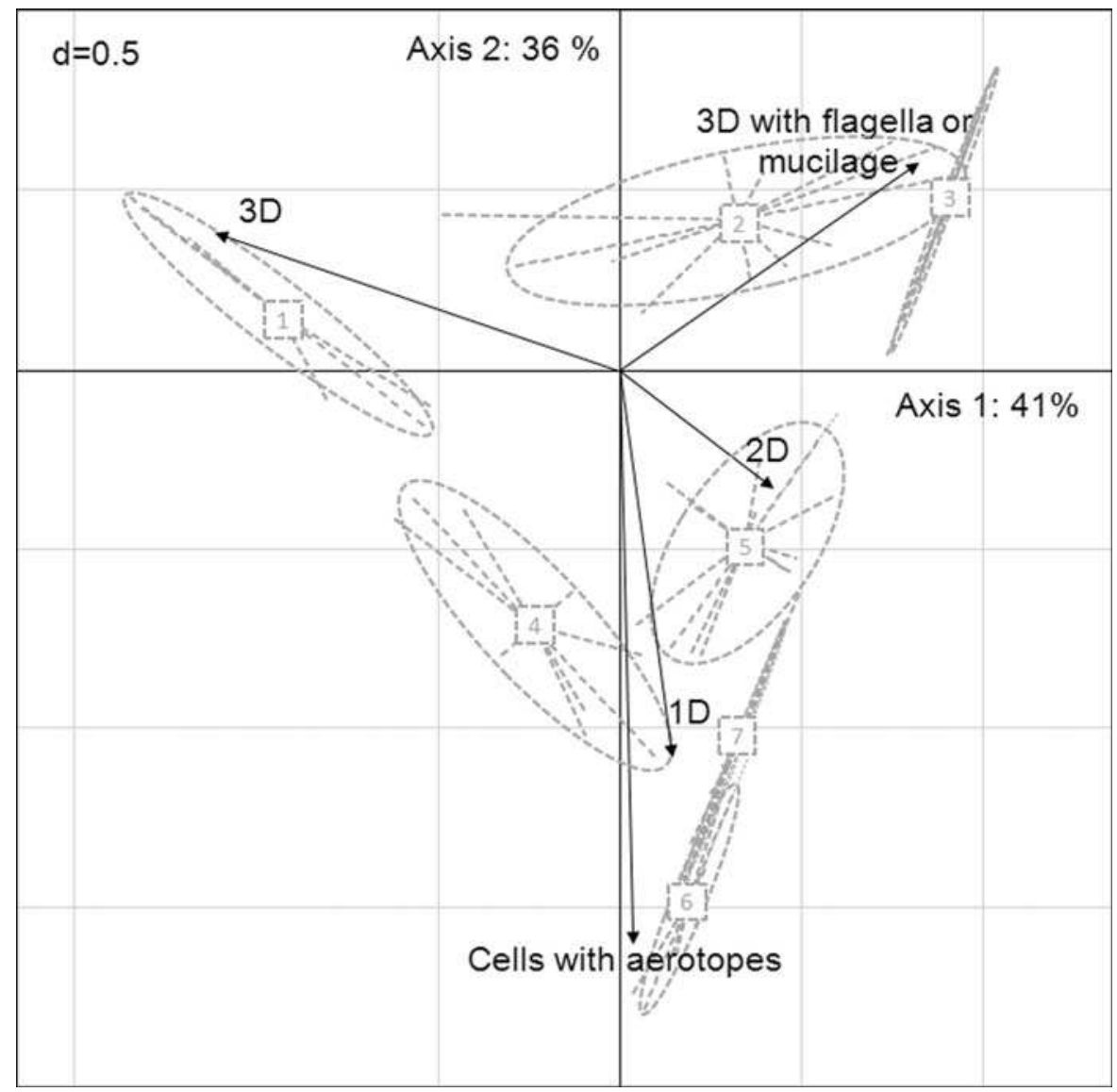

differences between sites, and incorporation of cell size in our analyses would have been relevant.

Many studies have shown changes in phytoplankton biomass and community structure according to physical constraints. Here, we present a study in rivers that can explain these variations in terms of morphofunctional traits. Following this approach and choosing a wide selection of traits, we identified the most relevant traits explaining the phytoplankton community structure in these rivers (flagella, buoyancy regulation, and shape). As a morphofunctional approach reflects the main constraints in a given environment, which do not necessarily change according to seasonality, location can explain more variations in phytoplankton community structure than seasonality as was found in this study. However, although such an approach seems to be relevant in rivers, our results are solely based on two rivers. Further studies conducted with a larger dataset are essential to validate and generalize this approach, in a same trend as Kruk et al. (2011) did in lakes. This larger dataset should include rivers where phytoplankton is impacted by hydrodynamical conditions, light and nutrient availability, and grazing. It will imply to considerer morphological traits related to all these environmental conditions. Therefore, we expect that additional trait will be necessary. Individual cell size (MLD, volume) will be a key trait for both light (Finkel et al. 2004; Schwaderer et al. 2011) and nutrient acquisition (Litchman et al. 2007; Litchman and Klausmeier 2008; Tambi et al. 2009), while colony/filament size and possibly the presence of spines will reflect grazing pressure (Barton et al. 2013). Cell size is also a key feature in turbulent nutrient-depleted environment, since increase in nutrient uptake due to water motion depends on cell radius (Karp-Boss et al. 1996). However, Edwards et al. (2012) recently showed that there was no correlation between size and the half saturation constant for phosphate uptake, or the phosphate uptake affinity in freshwater species highlighting some limits of morphofunctional traits approaches. By contrast, these 
physiological traits differ across taxonomic groups (Edwards et al. 2012). Hence, morphofunctional approach in rivers still need to be combined with a taxonomic approach since it also brings crucial information on the benthic or pelagic origin of species.

Acknowledgments This work was supported by a grant from CNRS and Veolia Environment to Stéphane Fraisse. The authors thank Guillaume Bouger, Enora Briand, and Philippe Louâpre for their great help during sampling periods, and MariePaule Briand and Nathalie Josselin-Lebris for physicochemical analyses done in ABGC center in ECOBIO. Help for species identification was provided by Luc Brient, Katia Pobis, and Frédéric Rimet. The authors also thank the three referees for their fruitful corrections.

\section{References}

Abonyi A, Leitão M, Lançon AM, Padisák J (2012) Phytoplankton functional groups as indicators of human impacts along the River Loire (France). Hydrobiologia 698:233-249

Barnes H, Folkard AR (1951) The determination of nitrite. Analyst 76:599-603

Barton AD, Pershing AJ, Litchman E, Record NR, Edwards KF, Finkel Z, Kiørboe T, Ward B (2013) The biogeography of marine plankton traits. Ecol Lett 16:522-534

Becker V, Huszar VLM, Naselli-Flores L, Padisák J (2008) Phytoplankton equilibrium phases during thermal stratification in a deep subtropical water supply reservoir. Freshwater Biol 53:952-963

Bormans M, Condie SA (1998) Modelling the distribution of Anabaena and Melosira in a stratified river weir pool. Hydrobiologia 364:3-13

Bovo-Scomparin VM, Train S, Rodrigues LC (2013) Influence of reservoirs on phytoplankton dispersion and functional traits: a case study in the Upper Paraná River, Brazil. Hydrobiologia 702:115-127

Centis B, Tolotti B, Salmaso N (2010) Structure of the Diatom community of the River Adige (North-Eastern Italy) along a hydrological gradient. Hydrobiologia 639:37-42

Chételat J, Pick F, Hamilton PB (2006) Potamoplankton size structure and taxonomic composition: influence of river size and nutrients concentrations. Limnol Oceanogr 51:681-689

Condie SA, Bormans M (1997) The influence of density stratification on particle settling, dispersion and population growth. J Theor Biol 187:65-75

Descy JP, Gosselain V (1994) Development and ecological importance of phytoplankton in a large lowland river (River Meuse, Belgium). Hydrobiologia 289:139-155

Devercelli M (2010) Changes in phytoplankton morphofunctional groups induced by extreme hydroclimatic events in the Middle Paraná River (Argentina). Hydrobiologia 639:5-19

Dokulil MT (1994) Environmental control of phytoplankton productivity in turbulent turbid systems. Hydrobiologia 289:65-72
Dray S, Dufour AB (2007) The ade4 package: implementing the duality diagram for ecologists. J Stat Softw 22:1-20

Edwards KF, Thomas MK, Klausmeier CA, Litchman E (2012) Allometric scaling and taxonomic variation in nutrient utilization traits and maximum growth rate of phytoplankton. Limnol Oceanogr 57:554-566

Finkel Z, Irwin AJ, Schofield O (2004) Resource limitation alters the 3/4 size scaling of metabolic rates in phytoplankton. Mar Ecol Prog Ser 273:269-279

Gurbuz H, Kivrak E, Soyupak S, Yerli SV (2003) Predicting dominant phytoplankton quantities in a reservoir by using neural networks. Hydrobiologia 504:133-141

Hillebrand H, Dürselen CD, Kirschtel D, Pollingher U, Zohary T (1999) Biovolume calculation for pelagic and benthic microalgae. J Phycol 35:403-424

Huisman J, Arrayás M, Ebert U, Sommeijer B (2002) How do sinking phytoplankton species manage to persist? Am Nat 159:245-254

Jones RI (1988) Vertical distribution and diel migration of flagellated phytoplankton in a small humic lake. Hydrobiologia 161:75-87

Jowett IG (1993) A method for objectively identifying pool, run, and riffle habitats from physical measurements. N Zeal J Mar Fresh 27:241-248

Karp-Boss L, Boss E, Jumars PA (1996) Nutrient fluxes to planktonic osmotrophs in the presence of fluid motion. Oceanogr Mar Biol 34:71-107

Kruk C, Huszar VLM, Peeters ETHM, Bonilla S, Costa L, Lürling M, Reynolds CS, Scheffer M (2010) A morphological classification capturing functional variation in phytoplankton. Freshwater Biol 55:614-627

Kruk C, Peeters ETHM, Van Nes EH, Huzar VLM, Costa L, Scheffer M (2011) Phytoplankton community composition can be predicted best in terms of morphological groups. Limnol Oceanogr 56:110-118

Lagadeuc Y, Boulé M, Dodson JJ (1997) Effect of vertical mixing on the vertical distribution of copepods in coastal waters. J Plankton Res 19:1183-1204

Legendre P, Legendre L (1998) Numerical ecology, second english edition. Elsevier Scientific Publishing Company, Amsterdam

Litchman E, Klausmeier CA (2008) Trait-based community ecology of phytoplankton. Ann Rev Ecol Evol Syst 39:615-639

Litchman E, Klausmeier CA, Schofield OM, Falkowski PG (2007) The role of functional traits and trade-offs in structuring phytoplankton communities: scaling from cellular to ecosystem level. Ecol Lett 10:1170-1181

Longhi ML, Beisner BE (2010) Patterns in taxonomic and functional diversity of lake phytoplankton. Freshwater Biol 55:1349-1366

Lorenzen C (1967) Determination of chlorophyll and pheopigments: spectrophotometric equations. Limnol Oceanogr 12:343-346

Lund JWG, Kipling C, Le Cren ED (1958) The inverted microscope method of estimating algal numbers and the statistical basis of estimations by counting. Hydrobiologia 11:143-170

McGill BJ, Enquist BJ, Weiher E (2006) Rebuilding community ecology from functional traits. Trends Ecol Evol 21:178-185 
Mieleitner J, Borsuk M, Bürgi HR, Reichert P (2008) Identifying functional groups of phytoplankton using data from three lakes of different trophic state. Aquat Sci 70:30-46

Murphy J, Riley JP (1962) A modified single-solution for the determination of phosphate in natural waters. Anal Chimi Acta 27:31-36

Oksanen J, Blanchet FG, Kindt R, Legendre P, O'Hara RB, Simpson GL, Solymos P, Stevens MHH, Wagner H (2010) Vegan: community ecology package. R package version 1.17-2. http://CRAN.R-project.org/package=vegan

Padisák J, Soróczki-Pintér E, Rezner Z (2003) Sinking properties of some phytoplankton shapes and the relation of form resistance to morphological diversity of plankton-an experimental study. Hydrobiologia 500:243-257

Padisák J, Crossetti LO, Naselli-Flores L (2009) Use and misuse in the application of the phytoplankton functional classification: a critical review with updates. Hydrobiologia 621:1-19

Pannard A, Bormans M, Lagadeuc Y (2007) Short-term variability in physical forcing in temperate reservoirs: effects on phytoplankton dynamics and sedimentary fluxes. Freshwater Biol 52:12-27

R Development Core Team (2010) R: a language and environment for statistical computing. R Foundation for Statistical Computing, Vienna. http://www.R-project.org/

Reynolds CS (1980) Phytoplankton assemblages and their periodicity in stratifying lake systems. Holarctic Ecol 3:141-159

Reynolds CS (1994) The long, the short and the stalled: on the attributes of phytoplankton selected by physical mixing in lakes and rivers. Hydrobiologia 289:9-21

Reynolds CS (2006) Ecology of phytoplankton. Cambridge University Press, Cambridge

Reynolds CS (2007) Variability in the provision and function of mucilage in phytoplankton: facultative response to the environment. Hydrobiologia 578:37-45

Reynolds CS, Descy JP (1996) The production, biomass and structure of phytoplankton in large rivers. Arch Hydrobiol Supp 113:161-187

Reynolds CS, Huszar VLM, Kruk C, Naselli-Flores L, Melo S (2002) Towards a functional classification of the freshwater phytoplankton. J Plankton Res 24:417-428

Salmaso N, Padisák J (2007) Morpho-functional groups and phytoplankton development in two deep lakes (Lake Garda, Italy and Lake Stechlin, Germany). Hydrobiologia 578:97-112
Salmaso N, Zignin A (2010) At the extreme of physical gradients: phytoplankton in highly flushed, large rivers. Hydrobiologia 639:21-36

Schwaderer AS, Yoshiyama K, Pinto PT, Swenson NG, Klausmeier CA, Litchman E (2011) Eco-evolutionary differences in light utilization traits and distributions of freshwater phytoplankton. Limnol Oceanogr 56:589-598

Sherman BS, Webster IT, Jones GJ, Oliver RD (1998) Transitions between Aulacoseira and Anabaena dominance in a turbid river Weir pool. Limnol Oceanogr 43:1902-1915

Sommer U (1996) Plankton ecology: the past two decades of progress. Naturwissenschaften 83:293-301

Stankovic I, Vlahović T, Udovič MG, Várbíró G, Borics G (2012) Phytoplankton functional and morphofunctional approach in large foodplain rivers. Hydrobiologia 698:217-231

Stevenson RJ, White KD (1995) A comparison of natural and human determinants of phytoplankton communities in the Kentucky River basin, USA. Hydrobiologia 297:201-216

Sun J, Liu D (2003) Geometric models for calculating cell biovolume and surface area for phytoplankton. J Plankton Res 25:1331-1346

Tam D, Hosoi AE (2011) Optimal feeding and swimming gaits of biflagellated organisms. Proc Natl Acad Sci 108:10011006

Tambi H, Flaten GAF, Egge JK, Bodtker G, Jacobsen A, Thingstad TF (2009) Relationship between phosphate affinities and cell size and shape in various bacteria and phytoplankton. Aquat Microb Ecol 57:311-320

Tavernini S, Pierobon E, Viaroli P (2011) Physical factors and reactive silica affect phytoplankton community structure and dynamics in a lowland eutrophic river (Po river, Italy). Hydrobiologia 669:213-225

Vannote RLG, Minshall W, Cumins KW, Sedell JR, Cushing CE (1980) The River continuum concept. Can J Fish Aquat Sci 37:130-137

Violle C, Navas ML, Vile D, Kazakou E, Fortunel C, Hummel I, Garnier E (2007) Let the concept of trait be functional! Oikos 116:882-892

Weithoff G (2003) The concepts of 'plant functional types' and 'functional diversity' in lake phytoplankton-a new understanding of phytoplankton ecology. Freshwater Biol 48:1669-1675

Zhang M, Shi X, Yu Y, Kong F (2011) The acclimative changes in photochemistry after colony formation of the cyanobacteria Microcystisaeruginosa. J Phycol 47:524-532 